\title{
MATERNAL PERSONAL HYGIENE, SANITATION, FAMILY SIZE, AND THE RISK OF DIARRHEA IN CHILDREN UNDER FIVE: A PRECEDE-PROCEED MODEL IN SURAKARTA
}

\author{
Erick Zicof ${ }^{1}$, Setyo Sri Rahardjoº, Bhisma Murti1) \\ 1)Masters Program on Public Health, Universitas Sebelas Maret \\ ${ }^{2}$ )Faculty of Medicine, Universitas Sebelas Maret
}

\begin{abstract}
Background: Running counter to the widely accepted hypothesis, an earlier study in Indonesia reported that overall poor mother's food-hygiene practices did not contribute to the occurrence of diarrhea in Indonesian children. This study aimed to determine the associations between maternal personal hygiene, sanitation, family size, and the risk of diarrhea in children under five, using a PRECEDE-PROCEED model.

Subjects and Method: This was a cross sectional study carried out in Surakarta, Central Java, Indonesia, from February to April 2018. A sample of 200 children under five years of age were selected for this study by fixed disease sampling, comprising 100 children with diarrhea and 100 children without diarrhea. The dependent variable was diarrhea. The independent variables were maternal personal hygiene, sanitation, and family size. The data were collected by questionnaire. Data on diarrhea status were taken on medical record at Puskesmas (Community Health Center). The data were analyzed by multiple regression model. Results: Diarrhea in children under five was negatively associated with good maternal personal hygiene $(\mathrm{OR}=0.13 ; 95 \% \mathrm{CI}=0.06$ to $0.29 ; \mathrm{p}<0.001)$, good sanitation $(\mathrm{OR}=0.22 ; 95 \% \mathrm{CI}=0.11$ to $0.46 ; \mathrm{p}<0.001)$, and family size $\geq 4$ ( $\mathrm{OR}=$ $2.55 ; 95 \% \mathrm{CI}=1.28$ to $5.10 ; \mathrm{p}=0.008$ ). Nagelkerke $\mathrm{R}^{2}=39.4 \%$.

Conclusion: The risk of diarrhea in children under five is associated with poor maternal personal hygiene, poor sanitation, and family size $\geq 4$.
\end{abstract}

Keywords: personal hygiene, sanitation, family size, diarrhea, children under five

\section{Correspondence:}

Erick Zicof. Masters Program on Public Health, Universitas Sebelas Maret. Jl. Ir. Sutami No. 36A, Surakarta 57126, Central Java. Email: erickzicof@gmail.com. Mobile: +6281363425870 . 